\title{
Faxian and the Meaning of Bianwen 變文: The Value of His Biography to the Study of China
}

T. H. BARRETT

Emeritus

SOAS, London

tb2@soas.ac.uk

Keywords: Faxian, bianwen, 變文, Victor Mair, Karashima Seishi

DOI: https://dx.doi.org/10.15239/hijbs.02.01.01

Abstract: In 1989 Victor Mair published a monograph entitled T'ang Transformation Texts that has subsequently come to determine the translation used for the term bianwen 變文 in English as 'transformation'. In 1991 I published in the Journal of the Royal Asiatic Society a comment on Mair's monograph proposing that a passage in Faxian's biography noticed by some earlier scholars but not discussed by Mair suggested that other ways of construing the term were possible, and I have subsequently expanded on these remarks in passing. In 2016 the erudite Seishi Karashima published in the Annual Report of the International Research Institute for Advanced Buddhology, Soka University a review of the early evidence for the meaning of bianwen that likewise draws on Faxian, though his explanation differs from and makes no reference to mine. How does Faxian's evidence now stand? 
$A_{\text {perspective, would be incomplete without some acknowledg- }}^{\text {ny account of the narrative of Faxian's travels, from whatever }}$ ment of the man himself. Though no later storytellers embroidered his exploit with popular legends-as happened with the later Journey to the West-he was clearly an exceptional person. At an age when most of us begin to look forward to the prospect of retirement, he decided to undertake one of the most hazardous and lengthy journeys known to the world of his day, a decision that pays great testimony to his idealism. Yet in him idealism plainly did not eclipse an appealing humanity. One of the first things I noticed about him myself is how he mourned the loss of a companion who died on the way, and was able vividly to recapture the grief of this tragedy many years later. ${ }^{1}$ And everyone who has read his story no doubt remembers how it was an encounter with a Chinese object in India that prompted such homesickness that he was completely overwhelmed. ${ }^{2}$ And mindful of his obligations to his native land, he could not but launch on another equally risky journey at an even greater age to get himself back to China once more.

Recent careful research has established that Faxian's story as we now have it is not strictly autobiographical, but in part autobiography 'as told to' another or others, and the name of the person responsible for the transmitted version of 416 has been tentatively identified. ${ }^{3}$ Whoever was responsible, the outcome is a substantial piece of Chinese Buddhist prose, and even if it is shorter than many later narrative Buddhist texts, it is even so one of the longest surviving sequential texts composed by Buddhists in China before the sixth century, and it is its unusual role as a linguistic corpus that I wish to highlight in my remarks. The language of translations into Chinese has not unnaturally dominated linguistic research into

1 Barrett, 'Exploratory Observations', 100, note 3, a study primarily concerned with other, more elusive aspects of the emotions of Chinese pilgrims in India.

2 Among the many translations into European languages now available, I refer here to the recent French translation of J.-P. Drège, Mémoire sur les pays bouddhiques, 69, which provides the original Chinese on its facing pages.

3 Hu-von Hinüber, 'Case of the Missing Author'. 
early Chinese Buddhist sources, but over time Buddhists in China also evolved their own capacity to communicate within and beyond their community, though this process has bequeathed less copious materials, and has consequently been less well studied so far. Only the fully fledged forms of literature much more copiously attested by the Dunhuang manuscript evidence, and the more colloquial language of China's early Zen masters, have inspired researchers across the world to publish extensively. These lively fields of scholarship are frequently hampered by the comparative lack of evidence of earlier developments, especially before the eighth century. Such sources as there are can only be considered well known, so in what follows the discussion primarily concerns secondary scholarship; perhaps its only originality lies in the suggestion that scholarship usually considered as pertaining to different areas of research such as Buddhist and Daoist Studies may at times be profitably brought together in reviewing the current state of our understanding.

As it happens, amongst the slim corpus of early indigenous writings about Buddhism in China, the narrative of Faxian has preserved for scholars at least one linguistic usage that has been seen as vital to tracing the evolution of one of the most puzzling terms from the Dunhuang materials, namely the term bian 變, as used in the wellknown term bianwen 變文 itself. The conventional translation for this is 'Transformation Text', though the second element seems to suggest a certain literary status, and texts could also be referred to using the first character alone. 'Transformation', for better or worse, does convey something of the etymology of the usage, and I use it here as a convenient neutral placeholder, rather than insisting on any particular interpretation of the meaning of the Chinese. Even so, it is the intention here to review some of the evidence adduced to explain how this word came to typify a popular Dunhuang genre, and to this end many experts have already pointed to a passage in the Record of Buddhistic Kingdoms. ${ }^{5}$ This relates to a sort of parade that Faxian

4 This distinction is now made following Fraser, Performing the Visual, 177, and 283 , note 71 .

5 Faxian, Mémoire sur les pays bouddhiques, 72. 
witnessed in Sri Lanka in honour of the Buddha's tooth relic that passed between representations of the Buddha's past lives, for which some examples are given, including the 'transformation' or bian of Śyāma (Shan 睒). In 1991 I suggested-for reasons that I shall recapitulate shortly-that here the transformation in question signified a rebirth, or the story of a rebirth, a jätaka, in short, and that later usages developed from this. ${ }^{6}$ The story in question was certainly one that was very well known.

In 2016, however, Seishi Karashima 辛島静志 (1957-2019) published a reconsideration of the history of this word and allied terms that certainly caused me to ponder anew the likelihood of my hypothesis. I had admired Professor Karashima's diligence and erudition ever since I first encountered him many years ago as a visiting researcher at Cambridge, and he now brought to bear on the problem in question a considerable experience in using the corpus of Chinese translations from South Asian languages so as to examine the history of the Chinese language, an approach that lies entirely beyond my capacities. My own remarks here reviewing the evidence on the meaning of bianwen as I understood it were first drafted in the expectation that they might in due course prompt Professor Karashima to deploy his exceptional talents to clarify the many points that remained-and remain-unclear to me, so the news of his passing has left me very distressed not simply at the early loss of a much treasured colleague but also at the realization that this hoped for speedy resolution of my puzzlement by an expert whom I personally admired can never be. The field of Buddhist philology is scarcely likely to encounter another scholar of his unusual range and capacity in the near future, so I leave my doubts for some scholar probably as yet unknown to me to resolve, and put them on record simply as an inadequate tribute to one of the most outstanding researchers I ever met. To sum up the publication that reawakened my interest in Faxian, however, though his arguments are rigorously detailed and thoroughly documented, and should be carefully read in full, in essence they may be said to

6 Barrett, 'Origin of the term pien-wen'.

7 Grey, Concordance, 340-44 (s.v. Sāma) gives a synopsis and copious references. 
construe the transformations in view both in Faxian's account and in later sources as relating to form rather than to content. In short if the context is one of representations of birth stories, then as I understand the thrust of his argument the word 'transformations' denote images of the stories, not the stories themselves. ${ }^{8}$ But with no earlier examples to confirm or deny either interpretation within the context given in Faxian's narrative, it is difficult to make any choice.

There is, however, some material evidently-since it sees the Northern Wei persecution of Buddhism as a recent event-from the late fifth century that I have in the past suggested can be considered relevant to the meaning of the word.' This material is however not discussed in Seishi Karashima's study, probably since it is not of Buddhist origin. Rather, it is to be found in the Dunhuang manuscript P. 2004, a portion of the Huabu jing 化胡經 or Scripture on Laozis Conversion of the Barbarians, which preserves a small collection of Daoist verse. The last eighteen pieces in this little anthology, including two which form a sort of coda to the rest, are entitled 'Laozi shiliu bianci' 老子十六變詞, which to judge from the contents should be rendered 'Lyrics on the Sixteen Rebirths of Laozi'. This source has been drawn upon in connection with discussions of the meaning of bianwen, but only in relation to the significance of bian for art history-and yet an examination of the contents of the work shows that it has no connection whatsoever with questions of art history, or indeed any questions of representation at all. ${ }^{10}$ The contents are plainly Daoist, but include frequent references to Buddhist names and terms, and would seem to manifest in literary form the same type of mixing of

8 Karashima, 'Meanings of bian', 262.

9 I was unaware of the significance of this material in 1992, and I was also unaware of its mention in the study by Rao Zongyi 饒宗頤 (1917-2018) cited by Seishi Karashima, but drew attention to it more recently in Barrett, 'Preliminary considerations', 49.

10 This is the sense in which it is mentioned in passing by Rao Zongyi and thus by Karashima. Rao has in fact touched on the text several times beyond the study that Karashima cites, but as far as I am aware has never addressed the exact meaning of bian in the text in any of his publications. 
Daoist and Buddhist elements in art now well known through the analysis of certain examples of fifth century North Chinese sculpture by Stanley Abe and others. ${ }^{11}$

Now, as I was at pains to point out in 1991, we know that there was by Faxian's time a considerable background both to the notion that Laozi was born many times, just like the Buddha, and to the belief that he transformed himself, though at first the two ideas, which I described as 'macro-transformations' and 'microtransformations', seem to have been kept distinct. ${ }^{12}$ Dating the point at which the language of transformation was actually applied to Laozi's rebirths is, however, not as yet an easy issue to resolve. An ascription to a fourth century text of one promising-looking phrase indicating that Laozi 'responded with transformations according to the times' (應變随時) seems to me to represent an interpretative early Tang synopsis of a source that in its current version seems rather against the idea. ${ }^{13}$ The recent research of Stephen Bokenkamp has established that in general the belief in multiple lives for some such as Laozi is a notion that can be traced back some way, even if Buddhist ideas of inevitable rebirth for all seem only to have been absorbed and reworked in Daoist ways in Faxian's lifetime. ${ }^{14}$ But influences from jätaka translations do appear to have been involved in this process. ${ }^{15}$ Unfortunately, all the evidence that allows us to reconstruct these shifts relates to the Daoism of South China, and for the region that produced Faxian we have no evidence that has so far been used to trace the early development of the interactions so evident in the art of the area and in P. 2004, though one day a thorough study of the

11 Abé, Ordinary Images, 270-313.

12 Barrett, 'Alternative Hypothesis', 242-43.

13 This is in P. 2353, as transcribed in Meng, Daoshu jijiao, 546. Comparison with the supposed original passage in the Shenxian zhuan 神仙傳 reveals a quite contrary notion of Laozi's existence, and no indication that the phrases cited here were ever part of the text: cf. Campany, To Live as Long as Heaven and Earth, 194-96 (translation), 429 (textual notes).

14 Bokenkamp, Ancestors and Anxiety, 162-82.

15 Bokenkamp, 'The Prehistory of Laozi', 417-18. 
now gradually increasing amount of Daoist epigraphical evidence may clarify matters further. ${ }^{16}$ The hypothesis that a 'transformation' had by Faxian's time come to mean in local parlance something like a jātaka as depicted in a textual or artistic form must therefore remain no more than a hypothesis, even if it is a hypothesis encouraged by the Daoist evidence.

It is also a hypothesis that is as far as I can see not falsified by the next reference we find in our sources that would appear to be of the same type as the usage found in Faxian's story. ${ }^{17}$ This passage occurs in a famous description of the lost glories of the monasteries of Luoyang composed in the middle of the sixth century, but concerns the outcome of the journey made by the diplomat Song Yun 宋雲 and his monk companion Huisheng 慧生 into Central Asia in 518 to 522, a mission also mentioned in the dynastic history of the period. ${ }^{18}$ At issue are some objects that Huisheng brought home from his travels, though precisely what objects puzzled me in 1991. Though I do not believe that I have advanced much in my understanding of Buddhist material culture since then, I do feel that a tentative identification of the object most relevant to my argument is now possible.

The first item mentioned as having been brought back by $\mathrm{Hu}-$ isheng is in any case not problematic. It was some sort of model in metal of a very famous stupa, the Queli 雀離 Stupa of King Kanishka, the monument of which Max Deeg has recently written at length. ${ }^{19}$ This record, incidentally, suggests that miniature stupas, that staple

16 The current research of Gil Raz, at any rate, promises to throw at least some further light on the pre-Tang Daoism of North China beyond the information related to state institutions that may be found in the Standard Histories such as the Wei shu 魏書.

17 Cf. Karashima, 'Meanings of bian', 262-63; Barrett, 'Alternative hypothesis', 242, 245-46. For a translation with the original text, see Yang (Lourme, trans.), Mémoire sur les monastères bouddbiques de Luoyang, 153.

18 For an annotated version of the briefer Wei shu record of the mission, see Yu, Liang Han Wei Jin Nanbeichao, 491-505.

19 Deeg, 'Legend and Cult'. 
of Buddhist art, need not be generic, but may actually refer back to actual famous and much larger originals, an observation that would also seem to be true for something else that Huisheng brought back. The text adds, after its mention of the metal model, another item or items that he returned with, literally, 'and Śākyamuni's four stupa transformations' 及釋迦四塔變, a phrase translated by Seishi Karashima as 'reliefs (變) of four stūpas of S̄ākya(muni Buddha)'.

Now there is no disagreement about what the four stupas are, since from context they are not the four great stupas of India named by later pilgrims, but four structures of more local fame in Central Asia. ${ }^{20}$ Each was associated with commemorating the location of a particular tale of the Buddha's past life, and the four remained linked as the themes of artistic decorations even of at least one rather lavish stupa described in the narrative of the journey of Ganjin (Ch. Jianzhen) 鑑真 (688-763) to Japan in the mid-eighth century, as Karashima himself notes. Here too, the term that we are neutrally but provisionally rendering as 'transformations' is used, and Karashima, as before, uses 'reliefs' once more, although other recent translations vary. ${ }^{21}$

The objects in question, with their four-fold representations of the Buddha's past lives, have most recently been studied by Dorothy Wong in her account of Ganjin's role in the spread of Buddhist material culture, and her account traces evidence for their creation China back to the sixth century, though it is unclear whether this innovation can be directly and solely connected to the return of the 518-522 mission. ${ }^{22}$ Her conclusion is that these four-sided constructions were linked to the legend of the Aśokan distribution

\footnotetext{
20 Yang, Jan, Iida, Shotaro, and Preston, eds., Hye Ch'o Diary, 42.

21 The translation by Marcus Bingenheimer, in the online version is available
} for download. 'A Translation of the Tödaiwajō tōseiden', 24, appears to translate as 'story'; cf. the anonymous translation in 'Tō Daiwajō Tōseiden', 17, where it appears to be translated as 'image'.

22 See Wong, 'An Agent of Cultural Transmission', 68. But I note that the image she cites here from her earlier study, viz. Wong, Chinese Steles, 156, fig. 10.2 , if I have construed the reference correctly, seems to depict an object with 
of the Buddha's relics, for which they formed ideal reliquaries, representing the Buddha on the outside by his past actions and containing something indicative of his presence within, whether a text, a jewel, or some other relic form. It will be seen, however, that the reliefs on Huisheng's object seemingly did not depict the four stupas, but rather depicted the stories associated with them. In this context, and certainly in the later case of the object that Ganjin's party saw, the translation of 'a past life' therefore still seems to me entirely plausible. That the 'past lives' here were rendered in metal is no doubt to be understood in Huisheng's case from the specification concerning the companion piece to the reliquary-if 'reliquary' is how it was already understood-in the earlier part of the sentence; no term for 'a relief' would have needed to have been expressed. But again we are dealing with a balance of probabilities, and so again I see nothing that resolves the issue precisely.

But what would appear to be a more telling argument against the hypothesis that I advanced may perhaps be found in another passage examined by Seishi Karashima, one that I was unaware of before the publication of his study, and one that deploys his expertise in the study of translations. This is actually earlier than the sixth century passage just discussed, since it occurs in Taisho $\overline{0}$ Canon text number 1462, which is usually described as a translation of the well-known Vinaya commentary of Buddhaghoșa, a work that is listed as having been carried out by Samghabhadra in Guangzhou in 488-489. ${ }^{23}$ This

four towers on it, suggesting perhaps that the original text of the Luoyang qielan ji discussed here may have read 四變塔, 'Stupas of the four transformations', rather than 四塔變, 'reliefs of the four stupas', or however one chooses to translate the characters taken in the order given in the text as it currently stands. This would not be the only place where the current text of the Luoyang qielan ji has been found to contain an accidental inversion: cf. Rao, Rao Zongyi Daoxue wenji, 444 .

23 Karashima, 'Meaning of bian', 257-58. On the Chinese text, however, see Heirman, 'Chinese Samantapāsādikā and its School Affiliation'; it is clear that Chinese influences affected the translation, and this should be kept in mind in the discussion that follows. 
commentary of course still survives in Pāli, so where it uses the phrase 'various transformations' 諸變, the original language used in the passage can be checked.

The author in the section in question is discussing the different types of adornment that are permissible on various types of object that might be found in a monastery; Seishi Karashima offers from the original context two possible equivalents, and renders the meaning as 'decoration' or 'design'. But the equivalence does not appear to be problem free, if one looks at the Chinese, since the whole context is somewhat hard to grasp. Karashima appears to translate as 'big', for example, a collocation (倒巨) that occurs in the entire Chinese Buddhist Canon only in this text, and then only twice. One wonders if one is dealing with localisms, in which case any meaning of 'transformation' might be quite different from that current in North China. And since the precise equivalent in the Pāli seems slightly problematic, one further wonders if 'various transformations' is a gloss from Chinese assistants that has somehow been incorporated into the text. For conceivably where figurative decoration was permitted, which is what the sentence is about, the assistants might well have specified the possible content of the figurative work, namely jätakas.

Perhaps this argument may smack of special pleading on my part, but I cannot help thinking that this evidence, though early, is less than perfectly clear cut. And since we have now mentioned the possibility of regional variations in the sense of the word 'transformation' in the three or four contexts we have considered so far, it is also important to underline that at some point meanings seem to have shifted, or perhaps rather expanded, over the course of time as well. Plainly not everything that could be called a 'transformation' in the Dunhuang manuscripts falls within the normal definition of a jataka, and indeed one sees that the distinction between such a narrowly defined 'birth story' and an avadāna not involving the rebirth of the future Buddha seems to have had less importance in China in any case. What the term 'transformation' covered originally, if it came from a Daoist context, would have been life in another epoch, perhaps at first a much earlier epoch of current human history, but-if we postulate a process such as the one documented in the scriptures of South Chinese Daoism - by the late fifth century it came to mean 
a life that took place beyond such chronological boundaries; in Buddhist terms, in another kalpa.

Yet it is important to concede that this meaning probably did not remain entirely stable. By the seventh century the passages we have examined are joined by others that situate the term 'transformation' in an art historical context where the meaning of 'a life in another age' seems less appropriate. For the early eighth century Seishi Karashima was able to deploy two more translated texts where parallel passages may be consulted, one a Tantric text with a Sanskrit version, and one a portion of the Vinaya of the Mūlasarvāstivādins where the Tibetan translation offers an independent witness to the original, and in these the meanings 'statue' and 'painting' are offered. This broader meaning should occasion no surprise: by the early eighth century at least the Chinese language into which translations were made was not exactly the same as that of Faxian's time in the period before the Sui-Tang reunification, as linguistic research has begun to make clear. ${ }^{24}$

Perhaps it is possible to grasp the type of situation uncovered by Seishi Karashima's study by means of an analogy using the English language, though of course it is impossible to find any entirely appropriate close parallel. The religious traditions of Europe contain nothing remotely like the Buddhist conception of inevitable rebirth, beyond one or two hints of ancient beliefs similar to those of pre-Buddhist Daoism that some unusual figures might be a past hero come to life again, redivivus, to use the Biblical epithet hypothetically applied to John the Baptist. But in general all religious lives and religious events are treated as unique in the mainstream Western tradition, so we must make do with an illustration using another type of religious term.

In Christianity the crucifixion of Jesus is seen as in religious terms utterly unique and is situated in a particular point in time during the procuratorship of Pontius Pilate, though as a Roman penalty the practice was all too common. Yet in current English a 'crucifixion' may refer without further qualification to artistic representations of this event, either in three-dimensional sculpted form or in a painting.

\footnotetext{
24 I have in mind studies such as Wang, Chu-Tang Fodian cibui yanjiu.
} 
If a qualifying word is added, then it is the author of the painting who is named, as in 'Bellini's crucifixion'. The same usage may be applied also to textual materials. In 1887, for example, Sir John Stainer (1840-1901), a largely forgotten and not excessively talented British composer of church music, published an oratorio entitled The Crucifixion that sustained a certain vogue into the twentieth century, and in this case both the text and the musical score are included in the phrase 'Stainer's Crucifixion'. A word originally applied to content has thus become applied to form, and it is not inconceivable that a similar transition took place with the term bian, if originally in some contexts it could mean a 'life story'.

The situation is no doubt complicated in the case of the Chinese term because a 'transformation' was not necessarily a rebirth giving rise to a life story capable of representation in words or pictures, but could also-at least in some disyllabic expressions such as bianxian 變現—indicate some temporally less extended manifestation of a normally unseen dharmakaya or its Daoist equivalent, hence my earlier reference to 'macrotransformations' and 'microtransformations'. Bian is indeed a far less specific term than 'crucifixion', and in its capacity for semantic range is much more like an English word such as 'appearance', which may vary from uses such as 'the appearance of the alphabet in the Western Mediterranean took place at a much earlier date than was originally thought' through to 'his appearance suggested that he had been drinking heavily'. In the seventh century Buddhist encyclopaedia Fayuan zhulin, it is used as a tag at the end of miraculous stories, as are other words such as yan 驗, 'a verification', or $q i$ 奇, 'an anomaly'. But while the main section of the work that uses this tag is devoted predominantly to what might be termed metamorphoses, in another section the meaning seems to be more connected with deviations from an expected norm, suggesting a usage closer to the contemporary Japanese hen 変, or 'strange'. ${ }^{25}$

Under such complex circumstances my own preference is to

25 The first set of tags may be found in section 25 , which is in the thirty-second fascicle; the second in a botanical section, the seventy-second, in the sixty-third fascicle (out of one hundred), $T$ no. 2122, 53:530a-b and 796a respectively. 
maintain an open mind on the history of the term. It is entirely possible that the meanings documented for the Tang period might securely be projected back into earlier sources, which would render my 1991 hypothesis redundant. But though the copious materials brought forward in Seishi Karashima's publication of course merit further evaluation, and here I have only reviewed a fraction of them, without reference either to the many other scholarly contributions to the problem that have been made in East Asia, I hesitate at this point to come to that conclusion. Others may, however, be in a position to resolve my doubts. Whatever views are taken, however, the evidence provided by the narrative of Faxian's travels will undoubtedly retain its unparalleled importance.

\section{Bibliography}

Abbreviation

T Taishō shinshū daizōkyō 大正新脩大蔵経. See Bibliography, Secondary Sources, Takakusu and Watanabe, eds.

\section{Primary Sources}

Fayuan zhulin 法苑珠林 [Pearl Forest of the Garden of the Dharma]. 100 juan. By Daoshi 道世 (seventh century), ca. 668. References made to $T$ no. 2122 , vol. 53.

\section{Secondary Sources}

Abé, Stanley K. Ordinary Images. Chicago: University of Chicago Press, 2002.

Anonymous. 'Tō Daiwajō tōseiden' 唐大和上東征傳 [The Great Master of the Tang Travels East]. TRADITIONS 伝統 2, no. 1 (1977): 7-44.

Barrett, T. H. 'Exploratory Observations on Some Weeping Pilgrims'. In The Buddhist Forum, Volume One, edited by T. Skorupski, 99-110. London: School of Oriental and African Studies, 1990. 
- - - 'The Origin of the Term Pien-wen: An Alternative Hypothesis'. Journal of the Royal Asiatic Society, Third series, 2, no. 2 (1992): 241-46.

- _ - 'Preliminary Considerations in the Search for a Daoist Dhammapada'. In Daoism in History: Essays in Honour of Liu Ts'un-yan, edited by Benjamin Penny, 41-55. London: Routledge, 2006.

Bingenheimer, Marcus. 'A Translation of the Tödaiwajō töseiden 唐大和尚東征傳. Part 1 [Rev. PDF edition, Part 1]’. 2003. https://www.academia.edu/3257332/A_Translation_of_the Tōdaiwajō_tōseiden_唐大和上東征傳._Part_1 ?auto=download. Bokenkamp, Stephen R. 'The Prehistory of Laozi: His Prior Career as a Woman in the Lingbao Scriptures'. Cabiers d'Extrême-Asie [Journal of the Far East] 14 (2004): 403-21.

Bokenkamp, Stephen R. Ancestors and Anxiety: Daoism and the Birth of Rebirth in China. Berkeley: University of California Press, 2007.

Campany, Robert Ford. To Live as Long as Heaven and Earth: A Translation and Study of Ge Hong's Traditions of Divine Transcendents. Berkeley: University of California Press, 2002.

Deeg, Max. 'Legend and Cult: Contributions to the History of Indian Buddhist Stūpas, Part 1: The Stūpa of Kanișka'. Buddhist Studies Review 21, no. 1 (2004): 1-34.

Faxian 法顯. Mémoire sur les pays bouddhiques 佛國記 [Record of Buddhistic Kingdoms], translated by J.-P. Drège. Paris: Les Belles Lettres, 2013.

Fraser, Sarah E. Performing the Visual: The Practice of Buddhist Wall Painting in China and Central Asia, 618-960. Stanford: Stanford University Press, 2004.

Grey, Leslie. A Concordance of Buddhist Birth Stories. 3rd ed. Oxford: The Pali Text Society, 2000.

Heirman, Ann. 'The Chinese Samantapāsādikā and its School Affiliation'. Zeitschrift der Deutschen Morgenländischen Gesellschaft [Journal of the German Oriental] 154, no. 2 (2004): 371-96.

$\mathrm{Hu}$-von Hinüber, Haiyan. 'The Case of the Missing Author: Who wrote the Anonymous Epilogue to Faxian's Foguo ji?' Annual Report of the International Research Institute for Advanced Buddhology at Soka University for the Academic Year 201216 
(2013): 307-14.

Karashima, Seishi. 'Meanings of bian 變, bianxiang 變相, and bianwen 變文'. Annual Report of the International Research Institute for Advanced Buddhology at Soka University for the Academic Year 2015 19(2016): 257-78.

Meng Wentong 蒙文通. Daoshu jijiao shizhong 道書辑较十種 [Ten editions of Daoist texts]. Chengdu: Bashu shushe 巴蜀書社, 2001.

Rao Zongyi 饒宗頣. Rao Zongyi Daoxue wenji 饒宗頣道學文集 [Rao Zongyi's Collected Writings on Daoist Studies]. Hong Kong: Cosmos Books, 2016.

Takakusu Junjirō 高楠順次郎, and Watanabe Kaigyoku 渡邊海旭, eds. Taishō shinshū daizōkyō 大正新修大藏經 [Buddhist Canon Compiled under the Taishō Era (1912-1926)]. 100 vols. Tokyo: Taishō issaikyō kankōkai 大正一切經刊行會, 1924-1932.

Wang Shaofeng 王紹峰. Chu-Tang Fodian cibui yanjiu 初唐佛典詞 彙研究 [Research into the Vocabulary of Early Tang Buddhist Materials]. Hefei: Anhui jiaoyu chubanshe 安徽教育出版社, 2004. Wong, Dorothy C. Chinese Steles: Pre-Buddhist and Buddhist Use of a Symbolic Form. Honolulu: University of Hawai'i Press, 2004.

Wong, Dorothy C. 'An Agent of Cultural Transmission: Jianzhen's Travels to Japan, 743-63'. In China and Beyond in the Mediaeval Period: Cultural Crossings and Inter-Regional Connections, edited by Dorothy C. Wong and Gustav Heldt, 63-99. New Delhi: Manohar Publishers, 2014.

Yang, Han Sung, Jan Yün Hua, Shotaro Iida, and Lawrence W. Preston, eds. The Hye Ch'o Diary: Memoir of the Pilgrimage to the Five Regions of India. Berkeley: Asian Humanities Press, and Seoul: Po Chin Chai, 1984.

Yang Xuanzhi 楊後之. Mémoire sur les monastères bouddhiques de Luoyang 洛陽伽藍記 [Record of Buddhist Monasteries of Luoyang], translated by Jean-Marie Lourme. Paris: Les Belles Lettres, 2014.

Yu Taishan 余太山. Liang Han Wei Jin Nanbeichao zhengshi Xiyu zhuan yao zhu 两漢魏晋南北朝正史西域傳要注 [Key annotations to the records of the Western Regions in the Standard Histories of the Han, Wei and Northern and Southern Dynasties]. Beijing: Zhonghua shuju 中華書局, 2005. 